University of Nebraska - Lincoln

DigitalCommons@University of Nebraska - Lincoln

Educational Psychology Papers and

Publications

Educational Psychology, Department of

2008

Relational Aggression: Not Just a Female Issue

Susan M. Swearer Napolitano

University of Nebraska-Lincoln, sswearernapolitano1@unl.edu

Follow this and additional works at: https://digitalcommons.unl.edu/edpsychpapers

Part of the Educational Psychology Commons

Swearer Napolitano, Susan M., "Relational Aggression: Not Just a Female Issue" (2008). Educational Psychology Papers and Publications. 142.

https://digitalcommons.unl.edu/edpsychpapers/142

This Article is brought to you for free and open access by the Educational Psychology, Department of at DigitalCommons@University of Nebraska - Lincoln. It has been accepted for inclusion in Educational Psychology Papers and Publications by an authorized administrator of DigitalCommons@University of Nebraska - Lincoln. 


\section{Relational Aggression: Not Just a Female Issue*}

\section{Susan M. Swearer}

Department of Educational Psychology, University of Nebraska-Lincoln, Lincoln, Nebraska, USA; sswearernapolitano1@unl.edu

Keyword: Relational aggression

"I got the conch," said Piggy indignantly.

"You let me speak!"

"The conch doesn't count on top of the mountain," said Jack, "so you shut up."

"I got the conch in my hand."

"Put on green branches," said Maurice. "That's the best way to make smoke."

"I got the conch-"

Jack turned fiercely.

'You shut up!' (Golding, 1954, p. 43)

In 1954 William Golding wrote the Lord of the Flies, an allegorical tale of a group of British school boys marooned on an island. Alone, without adult supervision, the boys create their own rules and society. Aggression and the development of aggression is one of the main themes in the book. As the dialogue above illustrates, the aggression among the boys starts as verbal aggression and then, over time, becomes more physical and finally, violent. This book, written over 60 years ago, recognized that relational aggression and physical aggression co-existed, were not mutually exclusive, and existed among boys.

The Gender Dichotomy in Aggression

In recent decades, relational aggression has been type-cast as a female form of aggression and the literature has focused on the "gender dichotomy" in our understanding of aggressive behaviors (Espelage, Mebane, \& Swearer, 2004). Girls have been characterized as more relational aggressive (e.g., threatening to withdraw from a relationship and manipulating relationships to damage others) than boys (Crick \&

Article history: Received August 26, 2008; accepted August 26, 2008; posted in the University of Nebraska-Lincoln institutional repository May 4, 2012.

*Commentary to appear in the special issue of the Journal of School Psychology, "The social ecology of relational aggression and bullying among school-aged youth." 
Grotpeter, 1995); and boys have been characterized as more physically aggressive than girls (Moffitt, Caspi, Rutter, \& Silva, 2002). However, other researchers have found no or weak gender differences in relational aggression (Kuppens, Grietens, Onghena, Michiels, \& Subramanian, 2008-this issue; Prinstein, Boergers, \& Vernberg, 2001; Rose, Swenson, \& Waller, 2004). Our understanding of gender differences in aggressive behavior and how this affects the developmental progression of bullying and relational aggression among school-aged youth is murky, at best.

The gender oversimplification of relational aggression has been fueled by the popular press, which has depicted relational aggression as a "female" form of aggression. Movies like "Mean Girls" and reality T.V. shows like "Big Brother" depict relational aggression as the forum for girls' aggression. Books such as Odd Girl Out (Simmons, 2002), Queen Bees and Wannabes (Wiseman, 2002), Please Stop Laughing at Me: One Woman's Inspirational Story (Blanco, 2003), and Girl Wars (Dellasega \& Nixon, 2003) assert that relational aggression is the domain for girls' aggressive behaviors. However, we also know that group exclusion and relational aggression are detrimental for boys (Swearer, Turner, Givens, \&Pollack, 2008)and that girls can also engage in physically aggressive behaviors (Prothrow-Stith \& Spivak, 2005). It appears that the "gender dichotomy" in aggression has been oversimplified in both the popular and research literatures. This special issue in the Journal of School Psychology on bullying and relational aggression helps to rectify this oversimplification.

\section{What is Relational Aggression?}

Relational aggression has traditionally been viewed as a "girls" form of aggression (Simmons, 2002; Underwood, 2003). Various terms have been promulgated to describe this phenomenon: indirect aggression, social aggression, and relational aggression. Indirect aggression is defined as "social manipulation, attacking the target in circuitous ways" (Osterman et al., 1998, p. 1). Social aggression is characterized as behaviors that are directed toward causing harm to another person's self-esteem and/or social status (Underwood, 2003). Relational aggression is described as "behaviors that are intended to significantly damage another child's friendships or feelings of inclusion by the peer group" (Crick \& Grotpeter, 1995, p. 711). Characteristic behaviors of these forms of aggression include spreading rumors, excluding peers from one's social group, withdrawing friendship or acceptance, and damaging relationships in order to hurt another individual. Each of these terms in the extant literature is used to describe behaviors that are relational in nature, involve damaging the victim's relationships and do not include the use of physical aggression.

Researchers have started to question whether males as a group are more aggressive (when relational aggression is included in the conceptualization of aggression) than females and whether females as a group engage in more relational aggression than males. In the past, studies on aggression have excluded girls from samples, making comparisons between males and females impossible (Crick \& Rose, 2001; Espelage et al., 2004). Additionally, studies on aggression have historically only included phys- 
ical behaviors. If the definition and measurement of aggression included relational behaviors, than the "gender dichotomy" in aggression would be less pronounced (Crick \& Grotpeter, 1995).

The four unsolicited, research articles in this special issue of Journal of School Psychology clearly advance our understanding of the complexity of relational aggression among school-aged youth. As a group, these articles advance our knowledge regarding gender issues in aggression and bullying. Each study includes both males and females in their samples and not surprisingly, the gender differences in relational aggression are small or non-existent. The articles in the special series also span the social ecology in which aggression and bullying reside, namely, the individual, peer, classroom, school, and family. As such, the applicability to understanding this phenomenon from a social-ecological perspective is further advanced through this series of articles.

\section{Social-Ecological Framework for Relational Aggression and Bullying}

The social-ecological framework of bullying behaviors (Swearer \& Espelage, 2004) challenges us to conceptualize these behaviors as being influenced by presence of favorable conditions in each domain that support the engagement in these behaviors. Just as the conditions (stress; no parental supervision; fighting for resources, etc.) on the island in Lord of the Flies supported the emergence of relationally and physically aggressive behaviors, individual, peer, classroom, school, family, and societal contexts either foster or inhibit the emergence of bullying and relational aggression. The articles in this special series further advance our knowledge about the conditions which contribute to bullying and relational aggression among school-aged youth.

Bullying and relational aggression have been most widely conceptualized as a group process (Espelage, Holt, \& Henkel, 2003; Salmivalli, Lagerspetz, Bjorkqvist, Osterman, \& Kaukiainen, 1996; Rodkin, 2004). Within the peer group, there are students who are engaging in bullying behaviors, students who are being bullied, and students who are observing the bullying interaction. The observers, or bystanders, are a critical group to understand. If bystanders can effectively intervene in the bullying interaction, then decreasing bullying in schools will become a reality. Gini, Pozzoli, Borghi, and Franzoni (2008-this issue) found that bystanders' behavior was directly related to students' sense of safety and that when bystanders were passive in the face of bullying, the peers assumed that they were supporting the bullying behavior. This study encourages educators and researchers to empower bystanders to actively intervene when they observe bullying behaviors. Students need to be educated about the detrimental consequences of passively observing bullying. Nickerson, Mele, and Princiotta (2008-this issue) found that both males and females were equally likely to be defenders or outsiders to the bullying interaction. Thus, while engagement in defending behaviors transcends gender, clearly the behavior of the bystander influences the conditions that allow bullying to occur (or not). 
In addition to establishing that bullying and relational aggression are peer group processes, research has also consistently shown that the school and classroom social ecologies can also set the conditions for bullying behaviors (Doll, Song, \& Siemers, 2004; Kasen, Berenson, Cohen, \& Johnson, 2004). Kuppens et al. (2008-this issue) found that not only was relational aggression stable over time, but that students who were in classrooms that supported relational aggression used relationally aggressive strategies. Thus, the classroom norms for relational aggression created the conditions for students to engage in these behaviors. Kuppens and colleagues also found weak gender differences in relational aggression and posited that the inconsistencies in the literature might be due to researchers not studying the effects of the classroom context in this form of aggression. Teachers are vital for creating a positive climate in classrooms and schools. The teacher-student relationship has not been as widely studied in the bullying literature. Mercer and DeRosier's (2008-this issue) article found that a student's rejected status predicted lower teacher preference. Low teacher preference was also associated with increasing levels of loneliness and lower grades over time. The school and classroom climate are critical for the presence or absence of bullying and aggressive behaviors. Healthy teacher and student relationships are critical for reducing bullying and relational aggression.

In addition to individual, peer, classroom, and school characteristics influencing bullying and relational aggression (see Espelage \& Swearer, 2004), the role of family influences and parental attachment have also been understudied. Adding an important piece to our understanding of the family correlates in bullying, Nickerson et al. (2008-this issue) found that secure attachment to mothers was associated with students' identifying as a defender of those students who were bullied. They posit that youth who are securely attached are more likely to support peers who are victimized. Healthy relationships at home are likely to influence healthy relationships at school (Duncan, 2004). Thus, in order to reduce bullying and relational aggression in school, adults need to model and engage in healthy social relationships.

When left unsupervised, will youth engage in bullying and relational aggression? Research has unearthed many of the social-ecological conditions that contribute to bullying behaviors. Despite the proliferation of research on youth aggression and bullying, there is still much to discover. Armed with data and with methodologically sophisticated studies, such as the ones represented in this special issue, researchers can illuminate the dynamics of bullying and relational aggression. This illumination will inform bullying prevention and intervention practices with the hope of creating a positive ending by stopping bullying and relational aggression among youth.

For a moment he had a fleeting picture of the strange glamour that had once invested the beaches. But the island was scorched up like dead wood-Simon was dead - and Jack had... The tears began to flow and sobs shook him. He gave himself up to them now for the first time on the island; great, shuddering spasms of grief that seemed to wrench his whole body. His voice rose under the black smoke before the burning wreckage of the island; and infected by 
that emotion, the other little boys began to shake and sob too. And in the middle of them, with filthy body, matted hair, and unwiped nose, Ralph wept for the end of innocence, the darkness of man's heart, and the fall through the air of the true, wise friend called Piggy.

(Golding, 1954, pp. 234-235)

\section{References}

Blanco, J. (2003). Please Stop Laughing at Me: One Woman's Inspirational Story. Avon, Mass.: Adams Media Corporation.

Crick, N. R., \& Grotpeter, J. K. (1995). Relational aggression, gender, and social-psychological adjustment. Child Development, 66, 710-722.

Crick, N. R., \& Rose, A. J. (2001). Toward a gender-balanced approach to the study of socialemotional development: A look at relational aggression. In P. H. Miller \& E. K. Scholnick (Eds.), Toward a Feminist Developmental Psychology (pp. 153-168). New York: Routledge.

Dellasega, C., \& Nixon, C. (2003). Girl Wars: 12 Strategies That Will End Female Bullying. New York: Simon \& Schuster.

Doll, B., Song, S., \& Siemers, E. (2004). Classroom ecologies that support or discourage bullying. In D. L. Espelage \& S. M. Swearer (Eds.), Bullying in American Schools: A Social-Ecological Perspective on Prevention and Intervention (pp. 161-183). Mahwah, N.J.: Lawrence Erlbaum.

Duncan, R. D. (2004). The impact of family relationships on school bullies and victims. In D. L. Espelage \& S. M. Swearer (Eds.), Bullying in American Schools: A Social-Ecological Perspective on Prevention and Intervention (pp. 227-244). Mahwah, N.J.: Lawrence Erlbaum.

Espelage, D. L., Holt, M. K., \& Henkel, R. R. (2003). Examination of peer group contextual effects on aggression during early adolescence. Child Development, 74, 205-220.

Espelage, D. L., Mebane, S. E., \& Swearer, S. M. (2004). Gender differences in bullying: Moving beyond mean level differences. In D. L. Espelage \& S. M. Swearer (Eds.), Bullying in American Schools: A Social-Ecological Perspective on Prevention and Intervention (pp. 15-35). Mahwah, N.J.: Lawrence Erlbaum.

Espelage, D. L., \& Swearer, S. M. (2004). Bullying in American Schools: A Social-Ecological Perspective on Prevention and Intervention. Mahwah, N.J.: Lawrence Erlbaum.

Gini, G., Pozzoli, T., Borghi, F., \& Franzoni, L. (2008-this issue). The role of bystanders in students' perceptions of bullying and sense of safety. Journal of School Psychology, DOI: 10.1016/j.jsp.2008.02.001.

Golding, W. (1954). Lord of the Flies. New York: Riverhead Books.

Kasen, S., Berenson, K., Cohen, P., \& Johnson, J. G. (2004). The effects of school climate on changes in aggressive and other behaviors related to bullying. In D. L. Espelage \& S. M. Swearer (Eds.), Bullying in American Schools: A Social-Ecological Perspective on Prevention and Intervention (pp. 187-210). Mahwah, N.J.: Lawrence Erlbaum.

Kuppens, S., Grietens, H., Onghena, P., Michiels, D., \& Subramanian, S.V. (2008-this issue). Individual and classroom variables associated with relational aggression in elementary school-aged children: A multilevel analysis. Journal of School Psychology, DOI: 10.1016/j. jsp.2008.06.005.

Mercer, S.H., \& DeRosier, M.E. (2008-this issue). Teacher preference, peer rejection, and student aggression: A prospective study of the transactional influence and independent contributions to emotional adjustment and grades. Journal of School Psychology, DOI: 10.1016/j. jsp.2008.06.006. 
Moffitt, T. E., Caspi, A., Rutter, M., \& Silva, P. A. (2002). Sex Differences in Antisocial Behaviour, Conduct Disorder, and Violence in the Duneden Longitudinal Study. Cambridge, UK: Cambridge University Press.

Nickerson, A.B., Mele, D., \& Princiotta, D. (2008-this issue). Attachment and empathy as predictors of roles as defenders or outsiders in bullying interactions. Journal of School Psychology, DOI: $10.1016 /$ j.jsp.2008.06.002.

Osterman, K., Bjorkqvist, K., Lagerspetz, K. M. J., Kaukiainen, A., Landau, S. F., Fraczek, A., \& Caprara, G. (1998). Cross-cultural evidence of female indirect aggression. Aggressive Behavior, 24, 1-8.

Prinstein, M. J., Boergers, J., \& Vernberg, E. M. (2001). Overt and relational aggression in adolescents: Social- psychological adjustment of aggressors and victims. Journal of Clinical Child Psychology, 30, 479-491.

Prothrow-Stith, D., \& Spivak, H. R. (2005). Sugar and Spice and No Longer Nice: How We Can Stop Girls' Violence. San Francisco, Calif.: Jossey-Bass.

Rodkin, P. C. (2004). Peer ecologies of aggression and bullying. In D. L. Espelage \& S. M. Swearer (Eds.), Bullying in American Schools: A Social-Ecological Perspective on Prevention and Intervention (pp. 87-106). Mahwah, N.J.: Lawrence Erlbaum.

Rose, A. J., Swenson, L. P., \& Waller, E. M. (2004). Overt and relational aggression and perceived popularity: Developmental differences in concurrent and prospective relations. $D e-$ velopmental Psychology, 40, 378-387.

Salmivalli, C., Lagerspetz, K., Bjorkqvist, K., Osterman, K., \& Kaukiainen, A. (1996). Bullying as a group process: Participant roles and their relations to social status within the group. Aggressive Behavior, 22, 1-15.

Simmons, R. (2002). Odd Girl Out: The Hidden Culture of Aggression in Girls. New York: Harcourt.

Swearer, S. M., \& Espelage, D. L. (2004). A social-ecological framework of bullying among youth. In D. L. Espelage \& S. M. Swearer (Eds.), Bullying in American Schools: A Social-Ecological Perspective on Prevention and Intervention (pp. 1-12). Mahwah, N.J.: Lawrence Erlbaum.

Swearer, S. M., Turner, R. K., Givens, J. E., \& Pollack, W. S. (2008). “You're so gay!”: Do different forms of bullying matter for adolescent males? School Psychology Review, 37, 160-173.

Underwood, M. K. (2003). Social Aggression among Girls. New York: Guilford Press.

Wiseman, R. (2002). Queen Bees and Wannabes: Helping Your Daughter Survive Cliques, Gossip, Boyfriends, and Other Realities of Adolescence. New York: Crown Publishers. 